Appendix I: Field notes, in Krass, V.A., Vaitl, J.D., and Amoco Oil Co., 1986 Alaska fieldwork, Lisburne Peninsula and western De Long Mountains, Alaska

Krass, V.A., Vaitl, J.D., and Amoco Oil Co.

GMC DATA REPORT 459B

This GMC data report from the Amoco Heritage collection has been made available through funding from the FY2018 USGS National Geological and Geophysical Data Preservation Program, Grant Number G18AP00054. This project report is presented in its original format and has not been reviewed for technical content or for conformity to the editorial standards of DGGS. It should not be used or cited as reviewed data.

2019

State of Alaska

Department of Natural Resources

Division of Geological \& Geophysical Surveys

GEOLOGIC MATERIALS CENTER
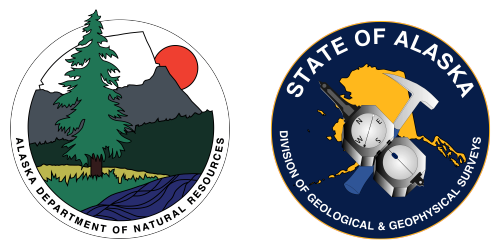
1986 AMOCO LISBURNE PENINSULA/DE LONG MOUNTAINS, ALASKA FIELD WORK

FIELD NOTES: Valerie Krass

Dates: $7 / 16 / 86-7 / 25 / 86$

Personnel: Valerie Krass Jon Vaitl

F. X. O'Keefe

Accommodations: Whalers Inn, Pt. Hope, Alaska

Transportation: ERA Helicopters

Len Paur - Pilot

Jet Ranger $390 \mathrm{EH}$

7/16/86: Wednesday - Arrive Point Hope, Alaska

Afternoon flight: reconnaissance of south

Lisburne Peninsula area.

Review Lisburne, Ogotoruk, Telavirak, Shublik, Siksikpuk, silurian-Ordovician

\section{7/17/86: Thursday}

NOTE: See Jack Schaefer of Tigara Native Corporation. Delivered check for $\$ 2,000.00$ for two days of 1 and access permit to Native lands. Pick up signed permit.

Objectives: Sample southern cliffs, become familiar with section.

Source rocks - collect any Lisburne shales, ?Penn. Kuna, Siksikpuk, ?Jurassic Ipewik, Ogotorok, Telavirik.

Reservoir - collect any Endicott sandstone, dolomites in Lisburne section, esp. Kogruk Formation.

Facies - examine all Jurassic/Lower Cretaceous, lower

Mississippian clastics, and Silurian-Ordovician section.

STOP ONE: 7-17-1 NW/4 22-T32N-R32W

L. Mississippian (?) Endicott

Interbedded mudstone, shale and limestone. Calcareous grainstone. Shallow marine environment. (?)Endicott or actually younger section equivalent to L. Miss. Lisburne.

Samples:

7-17-1A mudstone, black, blocky (Paleo, lith, source)

7-17-1B shale, black, slaty, blocky ( $P, L, S)$

7-17-1C limestone, carbonate grainstone, fossiliferous some solitary corals, ooids, etc. Medium grey. $(\mathrm{P}, \mathrm{L})$

7-17-1D shale, highly altered thick bed with abundant trace fossils. Too altered for source rock. (P,L)

7-17-1E dolomitic mudstone, to muddy dolomite. Blocky, bright orange on weathered surface. Possible wackestone. Dark grey fresh. Beds 4-6 feet thick, interbedded with 2-4 foot thick silty shales. (L) 
Samples:

7-17-2A Triassic shale (S,P)

7-17-2B Triassic shale ( $S, P$ )

$\frac{7-17-2 \mathrm{C}}{7-11 \text { iceous mudstone }(S, P, L)}$

7-17-2D siliceous micrite $w /$ bivalves on surfaces $(P, L)$

7-17-2E float, macro-fossil sample of bivalves - ? still in Triassic (P)

Continue down section further into fold.

7-17-2F (?) coaly shale, black, very soft, to mudstone if it is coal? is it marine in this stack of distal siliceous shales $(L, S, P)$

7-17-2G shale, siliceous, hard, dk grey ( $S, L)$

7-17-2H mudstone, siliceous, medium to dark grey, noncalcareous. ?Permian part of section $(P, L)$

7-17-2I mudstone, siliceous, $w / w t$. silica replacement of fossil. Lithostromic coral. ( $L, P$ ) ?Permian

7-17-2J shale, black, (?) Lower Cretaceous Ogotorok (P,S)

7-17-2K sltst-ss, $v$ fn gn, non-calcareous, interbedded w/dk gy shales, (?) Lower Cretaceous Ogotorok (L)

7-17-2L silty shale, black, (?) lower in Lower Cretaceous ogotoruk section (L)

Turbidites, Lower Cretaceous (?) rhythmically bedded shale and silt to fine ss $1 / 4$ to $1 / 2$ inch layers to occasionally blocky silty fine-grained sandstone.

7-17-2M ? lowermost Cretaceous or possibly Jurassic; shale, black, paper, sheared but apparently originally conformable contact. Just east of Agate Rock area ( $S, P)$

7-17-2N macro fossil sample, (?) Triassic bivalves in siliceous mudstone (P)

LUNCH - Point Hope (see Jack Schaefer)

Return to Agate Rock area, southern Cape Lisburne.

Investigate top of section for Triassic and Jurassic. Rain.

STOP THREE: 7-17-3 Location SW/4 36-T32N-R32W

7-17-3A shale, black, blocky but possibly silty ? base of lower Cret. or Jurassic $(P, S)$. Overlies directly in fault contact (?) - bedded siliceous mudst and $7-17-3 B$ chert and bivalves in $T$ shublik/otuk.

7-17-3C mudstone, siliceous, ?Triassic above fossil hash (polished sample) ( $P, L, S$ )

Question - How is Shublik/Siksikpuk contact defined here? ? by massive cherts.

STOP FOUR: 7-17-4 location NE/4 1-T31N-R32W Mouth of Imikrak Creek

7-17-4A shale, Permian (P, ?S)

Thinly interbedded shale and silt, siliceous, beds 8-16 inches, deformed, highly altered. Sample probably not good for source rock analysis. 
7-17-5A shale, black, probably lower cretaceous or possibly Jurassic $(P, S)$, non-siliceous

Lower Mississippian section. Marine interbedded lime grainstone (medium grey, some bivalves) and thick paper shales (black, fissile, weathered).

$7-17-6 \mathrm{~A}$ shale $(\mathrm{P}, \mathrm{S})$

7-17-6B limestone grainstone $(P, L)$

Question - Is this age equivalent facies to non-marine Endicott clastics now in proximity due to thrusting or is it actually younger basal Lisburne or Utokok?

Lime beds 6 inches to 2 feet thick. Section approximately 70 percent $\mathrm{sh} / 30$ percent Ls.

\section{7/18/86: Friday}

Morning - work south coastal area.

Weather: overcast, cold, light rain.

STOP ONE: 7-18-1 location E/2 4-T31N-R31W. Permo Triassic section.

7-18-1A shale, siliceous, dk gy slaty, hard, forms more resistant knobs ( $P, S-u n l i k e l y$ )

7-18-1B shale, v. weathered, forms recessive ledges, very poorly exposed. Triassic 2-bags ( $P, S$ )

7-18-1C ?Permo-Triassic, shale, siliceous, fissile but not too blocky ( $S, P)$

7-18-1D ?KJo - Ogotoruk; shale, black, v. little silt, no sand in section. Highly deformed $(P, S)$

\section{STOP TWO: 7-18-2 SE/4 12-T31N-R31W}

7-18-2-A Lower Cretaceous KJt - Telavirik. Coarse sandstone interbedded $\mathrm{w} / \mathrm{black}$ shales, moly-looking mineralization, deformed-difficult to see sed structures. Section-greywackes-trubidites

7-18-2B shale, KJt, weathered, prob too poor for source analysis (P)

Rhythmically bedded, sharp bases, fining upward, but hard to discern, 1-2 inch bedding.

STOP THREE: 7-18-3 NW/4 17-T31N-R3OW

KJt - Telavirik, upper part of section. Very fn gn ss-siltst. No good shale to collect. Very intensely folded.

7-18-3A sandstone, v. fn gn, dirty-argillaceous (L)

STOP FOUR: 7-18-4 SW/4 15-T3IN-R3OW

Kisimilok - Lower Cretaceous.

Interbedded $\mathrm{v}$. fn. gn. sandstone, primarily siltstone and silty shales. Very thinly interbedded. Disrupted. Dark grey. Kiktoya Creek.

$7-18-4 \mathrm{~A}$ siltstone (L)

$\overline{7-18-4 B}$ shale $(P, S)$ 
Lower Cretaceous Kisimilok shale. Very shaly section, little silt, no sandstone.

7-18-5A sh $(P, S)$

STOP SIX: 7-18-6 NW/4 34-T32N-R29W

Fortress Mountain Turbidite section.

7-18-6A sandstone, coarse to med grained, very dirty, many black sil. mudstone - chert clasts, siliceous cement, non-calcareous, fining upward, dominantly sandstone section, 2 foot thick sequences. Some massive ss beds to $\sim 6$ feet thick (L)

7-18-6B silty shale, ? gas source ( $P$, S-gas)

STOP SEVEN: $7-18-7 \quad$ NW/4 $10-T 32 \mathrm{~N}-\mathrm{R} 29 \mathrm{~W}$

Lower Cretaceous Kisimilok turbidites. Section dominantly silty black shale with rhythmically interbedded 1-2 inch silty ss.

7-18-7A shale $(P, S)$

LUNCH

STOP EIGHT: 7-18-8 SE/4 26-T33N-R29W

Basal lower Cretaceous Kisimilok section.

7-18-8A fine ss (L)

$\underline{7-18-8 B}$ shale, black, silty $(P, S)$

Highly deformed, fairly sand-rich with 8 inch massive sandstone, gy with numerous thin to moderate bedded ss/sltst/sh.

STOP NINE: $7-18-9 \quad$ SW/4 7-T33N-R29W

Top of KJo - Ogotoruk Fm. Very distal shaly turbidites. Very little silt, no ss.

7-18-9A shale, black, fissile, deformed $(P, S)$

STOP TEN: 7-18-10 NE/4 12-T33N-R3OW

Kukpuk River

Base of KJo - Ogotoruk Fm in thrust contact area with

Lisburne. 4-5 inch ss beds interlayered with silty

shale. Ss-medium-grained, dirty, micaceous, brown-grey weathering. Rhythmically bedded.

$7-18-10 \mathrm{~A}$ is (L)

7-18-10B silty shale - thin interbeds, prob too weathered for source $(P, S-$ ? )

Outcrops $50 / 50$ to $60 / 40 \mathrm{ss} / \mathrm{sh}$. 
Kogruk Lisburne

Interbedded black chert and buff microxalline dolomite. Beds 8-10 inches thick. 50/50 dol/chert.

7-18-11A dolomite and chert (I)

Depositional chert breccia along trend.

STOP TWELVE: 7-18-12 NW/4 10-T33N-R3OW

Across river to fault slice of Nasorak Fm undivided.

First appearance of section - looks like Mlnu-upper

Nasorak Fm - exposed along south cliffs just north of Cape Thompson at Imnakpak cliff.

? Here in fault contact w/Ogotoruk.

7-18-12A shale, silty, green-grey-black weathered. Mapped as ? KJo in fault contact w/MIn Lisburne $(P, S)$

7-18-12C light Lisburne - light grey to white weathering, fresh-light grey dolomite grainstone/wackestone, crinoidal to (?) pelletal with nodular black chert. 7-18-12B dark Lisburne - black shale (,$P$ )

Interbedded black shale and buff weathering dk gy limy dolomite or dolomite limestone - microxalline. Thinmoderate interbeds, 8-12 inches thick, 60/40 is/sh.

Flying River.

Triassic section near Angik Mountain. Bedded dark greyblack cherts/siliceous mudstones. No shale to sample. No stop.

\section{STOP THIRTEEN: NW/4 14-T33N-R31W}

Into main-central Permo-Triassic area. Poor outcrops. Land without sampling slaty siliceous shale - very shattered and rusty-highly weathered. No sample. still similar facies to coastal outcrops.

STOP FOURTEEN: SE/4 20-T34N-R3OW

Kagaksak Mountain Area

MIk - Lisburne Unit - Kogruk

Dolomitic Is - micritic w/occasional bryozoan, rare chert, occasional coral-solitary, crinoids. Weathers light grey, fresh-med-dk gy.

7-18-14A Jon's brachiopod

7-18-14B dolomitic mudstone. Kogruk dolomitic Is (L)

Alternating layers of dolomitic limestone - fossil hash grainstone w/bryozoan, crinoids, brachiopods, corals, etc., and dark grey dolomitic mudstone.

7-18-14C fossiliferous dolomitic limestone grainstone (L) (P) $\frac{7-18-14 \mathrm{D}}{\text { Bryozoan (P) }}$ (inear fossil "arrowhead necklace" ? 
Nasorak Fm, Lisburne Group. Interbedded, thinly bedded, black shale and limestone, 60/40 sh/ls. From air highly folded shale and 1 s beds with ls weathering lt orange-tan against black shale.

7-18-15A shale, black-very resinous appearance (S,P)

Permo Triassic fault sliver looks like chert or siliceous mudstone and poorly exposed shale. No stop due to proximity of wildlife.

\section{July 19: Saturday}

Lower Paleozoic-Mississippian section along coastline north of Point Hope.

STOP ONE: $7-19-1 \quad \mathrm{NE} / 4 \quad 33-\mathrm{T} 9 \mathrm{~S}-\mathrm{R} 61 \mathrm{~W}$

Section just south of Angolik River and south of previously measured sections at Cape Dyer and Angolik Creek (Amoco and Union).

7-19-1A sandstone float sample. Fine-medium grained, very siliceous ? Endicott non-marine $(L, \varnothing)$

B, C, D black shale, hard, fissile, very badly weathered. One graptolite sample in inner bag $\mathrm{C}$. ?SilurianOrdovician rock or lower Mississippian ( $P, S)$

E north of shale samples; dense black dolomite interbedded with shales

F south of shales; grey green phyllite

$\bar{G}$ south of shales; coarse-grained greywacke

South block - Silurian-ordovician - conglomeratic olistostrome with large blocks.

STOP TWO: W/2 28-T9S-R61W

Walking Endicott section to north, south of Cape Dyer.

Interbedded blocky shale and coal.

7-19-2A End. black shaly coal $(P, S)$

7-19-2B End. black blocky shale, no plant fragments apparent, weathered $(P, S)$

(RAIN, WIND)

$7-19-2 C, D$ shales (P, S )

7-19-2E Coarse-grained quartz sandstone, siliceous $(L, \varnothing)$

7-19-2F fine-grained qtz sandstone, dirty, siliceous $(L, \varnothing)$

$7-19-2 \mathrm{G}$ fn-med grained ss $\mathrm{w} /$ large woody fragment $(L, \emptyset)$ 7-19-2H black coal

7-19-2I medium grained, tite, It gy ss

Sandstones - coarsen and thicken upwards.

7-19-2J sandstone near top of section

LUNCH at STOP 3 
?Silurian-Ordovician section.

?heading up section.

7-19-3A coarse-gn wacke $(L, \varnothing)$

7-19-3B phyllite-slate $(L, P)$

Also loose samples of = facies - large for office.

Section - turbities - wacke, flysch.

Continue to search for graptolites without luck.

STOP THREE A: SW/4 5-T1OS-R61W

More of same, no samples.

STOP FOUR: $7-19-4 \quad$ SW/4 16-T1OS-R61W

Very large calcite vein in slates and fine wackes.

still in (?) Sil-ord. section. No graptolites found.

7-19-4A cobble of rounded, coarse grained wacke facies $(L, \varnothing)$

STOP FIVE: 7-19-5 NE/4 20-T1OS-R61W

From air section looks thinner bedded south from

original boulder-cobble beds at 7-19-1. Slates, wackes.

No graptolites.

7-19-5A 4-6 inch bed of carbonaceous soft black

?micaceous ?coal. Marine. ( $P, S, L)$

STOP SIX: 7-19-6 SW/4 29-T10W-R61W

Same as above with slightly cleaner coarse grained facies.

7-19-6A coarse gn wacke

STOP SEVEN: $7-19-7 \quad$ W/2 29-TIOS-R6IW

Just north of point. S/O looks finer-grained and shalier.

Lots of slate.

7-19-7A slate, no graptolites found (P)

STOP EIGHT: 7-19-8 SE/4 3-T9S-R61W

North of Cape Dyer. Looking for Geophoto mapped

Permo-Triasic.

7-19-8A shale, black, weathered $(P, S)$

STOP NINE: 7-19-9 E/2 4-T9S-R6IW

Coastal outcrop of Lisburne.

Fossiliferous limestone-grainst to wackest, with

brachiopods, lithostrotion corals, crinoids, etc.

$\underline{7-19-9 A}$ Is $(L, \varnothing, P)$

Massive bedded dark grey fresh, medium grey weathering, beds 2-6 inches thick alternating with thin black shales $\mathrm{w} / \mathrm{max}$. thickness of 8 inches. Shale too weathered (soft) to sample. Some micritic mudstones. 
Permo-Triassic. Poor outcrops of black shale in stream valley lowlands.

STOP ELEVEN: 7-19-11 SE/4 22-T7S-R6OW

Permo-Triassic (?) shale and chert. No-not PT-Mississippian Endicott or lowermost Lisburne (? probably not). Fine-med grained ss and shale - dk gy, loaded with large plant stems.

7-19-11A shale $\mathrm{w} / \mathrm{plant}$ fragments $(\mathrm{P}, \mathrm{S})$

July 20: Sunday

Plan: Fly to northern Lisburne Peninsula and collect Permo-Triassic and Lower Cretaceous. View Lisburne.

Also: Drop Tectosat geologists in northern area. Pick up in two days (Tuesday AM).

STOP ONE: $\quad 7-20-1$

$$
5,6-\mathrm{T} 7 \mathrm{~S}-\mathrm{R} 59 \mathrm{~W}
$$

Western shoreline Cliffs of Igrarok Hills.

Mapped as (?) K-Tr on geophoto.

Exposure: Thinly interbedded sand, silt and shale. Rhythmic layers, structurally disturbed but can discern fining upward cycles $\mathrm{w} / \mathrm{partial}$ Bouma sequences, including sharp bases, wavy and parallel bedding, etc.

One area of thick sand-channel. Shales show relatively abundant woody plant fragments to 1 inch diameter, and 4-6 inches in length.

7-20-1A coarse-grained ss from channelized section. One homogeneous, one graded. $(L, \emptyset)$

Sandstone generally 4 inches to 1 foot thick, except in vicinity of channel where they reach up to 2 1/2 feet thick.

$7-20-1 B$ shale (S)

7-20-1C shale (P)

7-20-1D shale $\mathrm{w} / \mathrm{plant}$ fragments and tool marks.

Folds and faults but no penetrative axial cleavage as seen in Silurian-Ordovician section.

7-20-1E shale $(S, P)$

Overall - section appears to be Lower Cretaceous turbidites ?Fortress Mtn.

STOP TWO: 7-20-2 NE/4 8-T7S-R59W

(?)Lower Cretaceous (?)Ogotoruk shales - section shalier here with float of pelecypod hash (Triassic nearby), with less abundant lighter weathering siliceous mudstones.

7-20-2A pelecypod hash - Triassic float (P)

7-20-2B shale, black, soft, fairly weathered $(P, S)$ 
7-20-2C V. fn. gn. thin interbeds of ss 6-8 inches thick, obviously distal turbidites

Proceed up hill to see if Triassic present. Hop to top of ridge - abundant light weathering pelecypod hash characteristic of Triassic.

Fly coast just cast of DEWLINE station. More thick, sand-rich turbidite section. (?)Fortress Mtn. (possibly Nanushuk). Abundant folding and some thick channelized sands. FX - some structural slides.

STOP THREE: 7-20-3 NE/4 8-T7S-R59W

(?) Permo-Triassic hillside.

7-20-3A slightly siliceous dk gy shale, fissile (P,S)

STOP FOUR: $7-20-4 \quad \mathrm{~S} / 2$ 16-T7S-R59W

Siliceous splintered mudstone to splintered red and green weathering siliceous shales. Bright red alteration.

7-20-4A shales, grey and red

Seeing two cleavages - one subparallel to beddingpenetrative, one at high angle to bedding.

Question: How come permo-Triassic rocks here have two cleavages? Are they the result of more than one event (i.e. pre-Brookian and Brookian) or two Brookian phases? Pencil cleavage?

STOP FIVE: $\quad 7-20-5 \quad$ NW/4 22-T7S-R59W

Low dark hills of Permo-Triassic siliceous mudstone and shale and light colored Lisburne.

No sample.

Triassic pelecypod hash - buff weathering.

LUNCH - sunny, breezy w/ocean view.

STOP SIX: 7-20-6 NW/4 17-T7S-R59W

Permo-Triassic against ridge of Lisburne.

Highly siliceous section with lots of blocky siliceous mudstone and chert. Thinly bedded. 2-6 inches. Some interbeds of grey-black shale.

7-20-6A black fetid shale (2 bags) (P,S)

Thick, thinly bedded sequence of siliceous mudstone and siliceous shale-siltstone.

Down stream-near helicopter find thin sandstone unit, v. fine-grained, micaceous, silty, grey-green, weathers rusty green. Thickness of main ss - approx. 12 feet thick. Highly structurally disturbed.

$7-20-6 B$ ss $(L, \varnothing)$

7-20-6C black shale - interbedded with sands, but may be faulting in hillside Age(?) - Triassic, Permian $(\mathrm{P}, \mathrm{S})$ 
7-20-6D ss (L) within 10 feet of definite Triassic Shublik pelecypod hash

STOP SEVEN: $7-20-7 \quad$ NW/4 $10-T 7 S-R 57 W$

Nanushuk Formation - interbedded ss/shale.

7-20-7A ss, fine to medium grained. Abundant plant fragments, wavy bedding, small scale channels $(L, \emptyset)$ 7-20-7B shale $(P, S)$

Delta plain sediments. No coals yet. FX - "40 miles offshore." Some coarsening upwards sequences. Sands to 2-3 feet thick. Meandering channels. Sand/shale ratio $\sim 50 / 50$.

STOP EIGHT: $7-20-8 \quad$ SE/4 36-T6S-R56W

Much further east up coast to see coaly section of Nanushuk Fm delta plain sequence.

7-20-8A coal (L)

Coal w/thick overlying channel with large cobbles and large tree detritus.

Sand channels and shale.

7-20-8B ss, med-coarse grained, cross-bedded $(L, \emptyset)$

\section{July 21: Monday}

$44^{\circ} \mathrm{F}$, heavy fog, light rain, windy.

Proceed to south coast to review Lisburne dolomite section - Kogruk Formation.

STOP ONE: $7-21-1 \quad \mathrm{SE} / 4 \quad 6-\mathrm{T} 31 \mathrm{~N}-\mathrm{R} 31 \mathrm{~W}$

Kogruk Fm, Lisburne Group. Start at west end of beach.

7-21-1A first unit - brecciated dolomite with black chert angular fragments and dolomite secondary cement. Little to no porosity $(L, \varnothing)$

7-21-1B black, bedded limestone. Smaller piece-bedded. Larger piece-in fault zone.

7-21-1C light brown-grey thinly bedded limestone - less dolomitic, mudstone. ?soaks acid slightly faster $(L, \emptyset)$

7-21-1D change in color to light buff-grey weathered and It. tan-gy fresh, striped dolomitic mudstone (micrite) with discontinuous med-grey laminae of dolomite in light brown grey dolomite. Laminae to $1-3 \mathrm{~mm}(L, \varnothing)$

7-21-1E light grey fresh and weathered limy dolomite. More coarsely crystalline $(L, \varnothing)$

7-21-1F dark to medium grey banded dolomite, slightly limy, some thin bands of dark grey chert which are associated with slightly limy layers. Thin layers $1 / 4$ to 1 inch thick.

7-21-1G into light grey to cream cross-bedded finely laminated limy crystalline dolomite. FX - macro photos of cross-beds, flaser bedding $(L, \varnothing)$

7-21-1H thinly interbedded dark grey-black chert and medium grey medium crystalline dolomite (?grainstone) 
No obvious beds to sample for paleo to age date. This portion of Lisburne section.

7-21-1I first sign to life. Light buff-grey wackestone with crinoids and unidentifiable fine fossil hash. Dolomitic wackestone $(P, L)$

7-21-1J brachiopod and bryozoan fossil hash. Dolomitic wackestone to grainstone. White to light-medium grey $(L, \emptyset, P)$

Into lower section - more grainstones.

STOP TWO: 7-21-2 SE/4 6-T31N-R31W

East along cliffs of Kogruk/Nasorak at Nasorak Creek.

?Upper Nasorak - of lowermost Kogruk: limestone crinoidal grainstone with some brachiopod and coral

fragments. Large crinoids to $1 / 2$ inch diameter.

Abundant geological coreholes (?paleomag). Some thin

interbeds of fissile limy shale with crinoid fragments and interbeds of dark chert. More thickly bedded here to 4-6 feet.

7-21-2A lime grainstone with larger fragments of brachiopods, lithostrotian coral, solitary corals, lots of crinoids, etc. Also still see thin zones $2-6$ inches thick of fissile dark grey shaly ls (P,L)

7-21-2B coarsely crystalline, light buff-grey, limestone $(\mathrm{L}, \varnothing)$

Into medium-grey fossiliferous dolomitic grainstone with interbedded dk grey-black chert. Grades to wackestone.

Thick section of thinly bedded lime wackestone, buff grey.

7-21-2C into light-grey to buff largely crinoidal bedded dolomitic wackestone-grainstone. Some coral and bryozoa $(L, P, \varnothing)$

East side of creek - lime crinoidal fossiliferous wackestone/packestone.

7-21-2D Lisburne dol. grainstone $(L, \emptyset)$

LUNCH

STOP THREE: 7-21-3 SW/4 30-T8S-R58W

North area Permo-Triassic.

Chert and shale with pelecypod float.

7-21-3A shale, siliceous, weathered $(P, S)$

$\overline{7-21-3 B}$ ?Lower Cretaceous shale down creek $(P, S)$

STOP FOUR: 7-21-4 SW/4 18-T8S-R58W

Walk east half in tight creek bed.

Top of creek - siliceous mudst and poorly exposed deeply weathered shale with float of pelecypod hash.

Into drainage - excellent black carbonaceous shale.

(?)Age - Lower Cretaceous (but looks more blocky and w/o sand) or Jurassic Ipewik or Triassic (but doesn't look siliceous enough). 
7-21-4A ?Paleozoic/Mesozoic black shale 2 bags (P,S)

7-21-4B down creek - strange orange-weathering (?) micronodular siltstone (L)

7-21-4C adjacent to above, shale $(\mathrm{P}, \mathrm{S})$

At confluence of drainage - chert/siliceous mudstone/ shale - (?)Permo-Triassic.

STOP FIVE: 7-21-5 SE/4 13-T8S-R59W

Miss/?Perm contact - appears conformable. Doesn't look like fault contact in stream cut.

7-21-5A uppermost part of Miss Lisburne Group. Fossiliferous lime grainstone and light-colored chert.

Basal Permian (?) - red/green weathering siliceous mudstones and very badly weathered rusty shale. Thin

bedded. Very silty. Minor chert.

7-21-5B dark grey blocky siliceous mudstone - shale, somewhat fissile. $V$. silty (P)

7-21-5C ?Permian dark grey silty shale with light gy linear fossils (?) (P)

7-21-5D black shale, weathered, above siliceous section. (?)Triassic-Jurassic-Permian. Similar soft black shale to other drainage but apparently sitting below Triassic pelecypod hash at ridge cap.

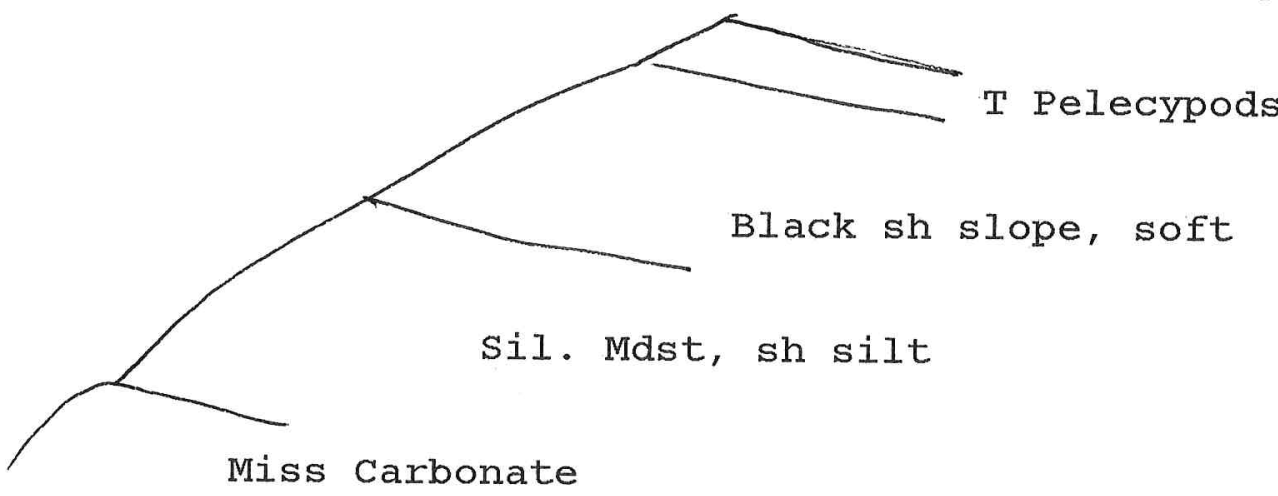

Exxon core location at top of hill.

STOP SIX: 7-21-6 SE/4 35-T9S-R58W

Lower Cretaceous - Ogotoruk Turbidites. Thinly interbedded sand and shale - Tungnak $\mathrm{Ck}$.

7-21-6A shale $(P, S)$

Rhythmically interbedded graded, v. fn. gn. ss, siltst, shale. Very distal. silt-sand-rust weathering. 1 inch

thick; intervening shales -1 to 6 inches thick, sd/sh $50 / 50$.

\section{STOP SEVEN: 7-21-7 SE/4 14-T10S-R59W}

Mapped as Lower Cretaceous Ogotoruk. Coarse sands, thicker to 4-8 inches thick, argillaceous.

$\underline{7-21-7 A}$ coarse ss $(L, \varnothing)$ 
July 22: Tuesday

Plans: 1) Transport Teetosat group to south shore

2) Check Lisburne at Cape Lewis

3) Check Lisburne at Niak Creek

4) Collect Ogotoruk at Ayugatak and Oligavik

Cks., esp. towards base

5) Check Geophoto Map - Miss - undivided.

STOP ONE: $7-22-1 \quad \mathrm{E} / 2$ 17, 20-T7S-R60W

Niak Creek Area - Lisburne Group.

Light to mediun grey limestone - mudstone with mud clasts, wackestone with crinoid/brachiopod hash, some lithostrotian corals and grainstones.

7-22-1A Lisburne Group - (?)Kogruk Fm dolomitemicrocrystalline, fossiliferous wackestone w/crinoids $(L, \varnothing)$

Interlayered limestone and dolomite, thickly bedded, 2-10 feet.

Zone of abundant hexagonal coral heads in lime mud matrix with some lithostrotian corals.

Reefal-biohermal in character, 50-100 feet thick hex coral unit.

Followed by thick zone of lithostrotian corals in micritic matrix.

$\frac{7-22-1 B}{(L}$ zone of crinoidal dolomite wackestone/grainstone

Return to Is mud system with hex corals and solitary

horn corals.

Thus far: 70 percent $1 \mathrm{~s} / 30$ percent dolomite.

7-22-1C fossil chip - horn coral, brachiopod, second piece - ? braching coral and crinoid stems (P)

Jon finds USGS sea mushroom - \$1 reward if returned to Menlo Park.

Into another corraline lime section - thick, lithostrotian.

Near end of beach - thick dolomitized breccia zone.

Tectosat camped near cliff spring. Pick up Thursday night $7 / 24$.

Shell - geologists working southern coasts near Agate Rock. Camped somewhere on Wilik RV.

STOP TWO: $7-22-2 \quad$ NW/4 28-T7S-R6OW

Just south of Rock Creek.

Limestone coral biohermal/mud facies. Photos 7-11 solitary horn corals, lithostrotian and thicker

(?) hexagonal head forms.

Maybe same unit as before. Some major open folding to south. 
7-22-2A section of buff to 1t. gy dolomite fossiliferous wackestone $(L, \emptyset, P)$

LUNCH

STOP THREE: 7-22-3 SE/4 36-T7S-R59W

?Lower Cretaceous black shale, silt, ss turbidite section. Ogotoruk.

7-22-3A shale, weathered $(P, S)$

Some reflective, almost coaly surfaces; sand-fine grained, $1 / 2$ to 2 inches thick. Scour marks, took marks $\mathrm{sd} / \mathrm{sh}$, about $50 / 50$.

STOP FOUR: $7-22-4 \quad$ NE/4 31-T7S-R58W

Down creek to next Ogotoruk section, more shaly; sd/sh about $40 / 60$.

7-22-4A shale, 2 bags $(P, S)$

SS-fn to med gn, slightly cleaner, 2-4 inches thick beds.

$\underline{7-22-4 B}$ ss $(L, \varnothing)$

STOP FIVE: $7-22-5 \quad$ SE/4 20-T7S-R58W

Lower Cretaceous Ogotoruk turbidites with ss beds

4-16 inches thick. $\mathrm{Ss} / \mathrm{sh}$ ratios $40 / 60$.

$\underline{7-22-5 A}$ shale $(P, S)$

Ss-fn to med grained, graded, tool marks.

STOP SIX: $7-22-6 \quad$ SW/4 29-T8S-R58W

Oligavik Creek - L.K. Ogotoruk.

$7-22-6 \mathrm{~A}$ shale, silty, tool marks ( $\mathrm{P}, \mathrm{S})$

$\overline{7-22-6 B}$ medium grained dark $s s(L, \varnothing)$

STOP SEVEN: $7-22-7 \quad$ NW/4 24-T8S-R58W

L.K. Ogotoruk.

7-22-7A shale $(P, S)$

$\overline{7-22-7 B}$ ss-channel $(L, \varnothing)$

Lower Miss. sed rocks undivided:

STOP EIGHT: 7-22-8 NE/4 28-T1OS-R6OW

Chert and limestone - Lisburne Group.

STOP NINE: $7-22-9 \quad$ W/2 16-T8S-R6OW

Okpilatok Bluff - major lithostrotian corals in Lisburne Group, south of Noyalik Peak.

STOP TEN: 7-22-10 SW/4 1-T8S-R6OW

Coarsely crystalline 1t. gy to buff limestone, crinoidfossiliferous wackestone on weathered surface $(L, \varnothing)$.

7-22-10A lime wackestone 
Also - lots of light colored chert.

Cape Lewis - hex coral limestone.

STOP ELEVEN: 7-22-11 SW/4 19-T11S-R6IW

Silurian-Ordovician. High angle cleavage to bedding.

$\frac{7-22-11 \mathrm{~A}}{7-22-11 \mathrm{~B}}$ slate (P)

July 23: Wednesday

De Long Mountains

STOP ONE: $7-23-1 \quad$ SE/4 20-T33N-R23W

Spiny Ridge - Plate 2 JPez

Shublik/Siksikpuk - interbedded black micritic limestone very fetid on fresh break and black fissile shales.

Limes weather buff to pale orange. Lime beds 6-8 feet

thick. Shales vary from thin interbeds (2-4 inches) to 4-6 feet.

7-23-1A shale (,$P$ )

$\overline{7-23-1 B}$ black is (S)

Flying north along spiny Ridge scanning Permo Triassic and (?) Jurassic.

STOP TWO: 7-23-2 N/2 9-T33N-R23W

?Okpikruak Fm - KO2 - in stream cut along Kukpuk RV.

Interbedded black blocky to nodular shale and thin fine grained, dirty sandstone. Sand 3-5 inches thick.

Rhymthically bedded turbidites. Dominantly shale.

$\mathrm{Sh} / \mathrm{ss} 75 / 25$.

$7-23-2 A$ shale $(P, S)$

STOP THREE: 7-23-3 SW/4 9-T33N-R23W

?Permo-Triassic interbedded green chert and thin green shales. Chert beds 2-4 inches thick, shales 2-4 inches thick. Sh/chert ratio $60 / 40$ to $70 / 30$.

7-23-3A shale, $v$. weathered, doubtful (P)

STOP FOUR: 7-23-4 E/2 1-T33N-R23W

SE side of Spiny Creek.

Interbedded siliceous mudst grading to chert, black with light brown weathering silty black (fresh) fetid limestone.

7-23-4A limestone (S,L)

$\underline{7-23-4 B}$ sil mast (I)

Continue along Kivalina Rv. north.

STOP FIVE: 7-23-5 NW/4 6-T33N-R22W

Contact zone. Permo Triassic (JPe)/Ipewik (Kji)/Okpikruak (Ko). 
Down to river. (?)Ko - thick medium grained ss, 2-8 inches thick beds with interbeds of silty shale.

?channels - more proximal turbidite facies.

$7-23-5 \mathrm{~A}$ ?Jurassic Ipewik shale $(P, S)$

$7-23-5 B$ ss $(L, \emptyset)$, Ko

$\overline{7-23-5 C}$ silty sh (P), Ko

STOP SIX: NW/4 32-T34N-R22W

Ko - $\underline{7-23-6 A}$ shale $(P, S)$

Interbedded shale and silt with some thin medium-coarse sandstone. Turbidite section without major channels as seen in last stop. Tool marks, ripples, upside down sequence. Sands 4-8 inches thick; sd/sh ratio about $50 / 50$.

Permian - siliceous mudst and chert.

Permo-Triassic - shales and siliceous mudstone.

STOP SEVEN: T3IN-R21W

Baird Group Devonian carbonates.

Lunch stop.

7-23-7A corals.

Red dog - refuel 50 gallons.

STOP EIGHT: $7-23-8 \quad \mathrm{~N} / 2 \quad 8-\mathrm{T} 34 \mathrm{~N}-\mathrm{R} 2 \mathrm{OW}$

Thrust Plate 1.

JPe: Shublik-Siksikpuk Fms. - Siliceous mudstone and chert and black shales.

7-23-8A black slate $(P, S)$

All Permian looks highly siliceous and even low grade $\mathrm{mm}$ in Plate One.

STOP NINE: 7-23-9 SW/4 3-T12S-R49W

Shublik-lots of hills with little exposure.

Interbedded chert and shale.

7-23-9A black shale $(P, S)$

STOP TEN: 7-23-10 SW/4 16-T12S-R5OW

?JPe interlayered silt and shale. Thin bedded. Less siliceous than before, no cherts obvious.

7-23-10A shale $(P, S)$

$\underline{7-23-10 B}$ (?) V. fine-grained ss $(L, \emptyset)$ 
Okpikruak turbidites - sh/ss ratio $70 / 30$.

7-23-11A shale $(P, S)$

Kukpuk Rv. headwater cut.

STOP TWELVE: 7-23-12 SE/4 16-T12S-R5OW

(?)KJi - Ipewik Fm. In stream cut - mostly highly oxidized red/brown/orange shale with some interbeds of light orange weathering siltstone.

$7-23-12 \mathrm{~A}$ siltstone (L)

$\overline{7-23-12 B}$ shale $(P, S) V$. weathered

\section{July 24: Thursday}

7-24-1A NW/4 2-T29N-R28W

Lower Cretaceous coarse grained sandstone.

7-24-2A NW/4 11-T29N-R28W

Banded chert and sil. mudst.

7-24-3 NE/4 2-T29N-R28W

No sample - green chert ?Permo-Triassic.

7-24-4 E/2 2-T29N-R28W

No sample - green siliceous mudstone.

7-24-5A SW/4 36-T30N-R28W

Interbedded green siliceous mudst plus chert and green shale. 2-4 inches bedding.

$\underline{A}$ - gn silty clayst (P)

7-24-6 SW/4 20-T29N-R27W

Float of black siliceous mudstone, chert outcrop and $\mathrm{v}$. fn. gn. green ss.

$\underline{A}$ - ss and black mdst $(L, P)$

7-24-7 NW/4 29-T29N-R27W

(?) Permian green chert.

Permian section (?) thicker than expected.

7-24-8 NW/4 16-T29N-R27W

black chert and limestone.

A - finely crystalline 1 s and chert coral fossil.

7-24-9 W/2 9-T29N-R27W

green fine-medium grained ss, V. argillaceous, age - unknown.

$\underline{A}$ - fine-med gn ss, V. micaceous $(L, \emptyset)$

$\underline{B}$ - shale w/abundant burrows, trace fossils. Marine $(P, S)$ 